\title{
Effects of forest type and stream size on volume and distribution of stream wood: legacies of wildfire in a Euro-Mediterranean context
}

\author{
Pedro G. Vaz ${ }^{1,6}$, Dana R. Warren ${ }^{2,7}$, Eric C. Merten ${ }^{3,8}$, Christopher \\ T. Robinson ${ }^{4,9}$, Paulo Pinto ${ }^{5,10}$, AND Francisco C. Rego ${ }^{1,11}$ \\ ${ }^{1}$ Centre of Applied Ecology "Prof. Baeta Neves", Institute of Agronomy, Technical University of Lisbon, \\ Tapada da Ajuda, 1349-017 Lisbon, Portugal \\ ${ }^{2}$ Department of Fisheries and Wildlife, Oregon State University, Corvallis, Oregon 97331 USA \\ ${ }^{3}$ Department of Biology, Wartburg College, Waverly, Iowa 50677 USA \\ ${ }^{4}$ Department of Aquatic Ecology, Eawag, 8600 Duebendorf, Switzerland and Institute of Integrative Biology, \\ ETH-Zürich, Zürich, Switzerland \\ ${ }^{5}$ Water Laboratory, Centre for Geophysics of Évora, University of Évora, Largo dos Colegiais, \\ 7001 Évora codex, Portugal
}

\begin{abstract}
Downed wood pieces are key links between terrestrial and aquatic ecosystems. They promote organic matter retention, create habitat, and potentially increase stream productivity. The stock of downed wood in a river system is a product of the interaction between wood supply, transport, in situ losses, and retention characteristics of the system. Fire and forest management are important disturbances that influence the amount and organization of stream wood with boom-and-bust periods of recruitment and fluvial transport processes. We examined $1^{\text {st }}$ - through $3^{\text {rd }}$-order Portuguese streams flowing through 3 common silvicultural systems in southern Europe: forests of cork oak, eucalyptus, and maritime pine. Our data set included 1483 pieces of wood in 27 streams, all of which had experienced extensive wildfires within the previous $6 \mathrm{y}$. We used binned neighbor- $k$ analysis to assess wood organization (segregated, random, or aggregated). We then used linear mixed-effects modeling to evaluate the effects of stream order, forest type, and their interaction on wood volume and organization. The best predictor of wood volume and organization was the interaction between forest type and stream order. Most wood pieces were burned and organization was low, suggesting that arrangement of wood was largely a product of input dynamics rather than transport processes at this time. Potential drivers of across-system variability included vegetation obstructions, wood length:channel width ratios, management actions, and effects of fire. Climate models predict more droughts in the Euro-Mediterranean region in the future, with implications for wood volume, transport, and function as terrestrial vegetation invades intermittent stream channels and plant communities shift from managed forests to shrublands with few trees.
\end{abstract}

Key words: wildfire, Portugal, wood distribution, wood volume, forest management, eucalyptus, cork oak, maritime pine, disturbance, intermittent streams.

Downed wood pieces are key links between terrestrial and aquatic ecosystems and promote organic-matter retention, create habitat, and increase productivity in streams (Naiman et al. 2002). The stock (amount and arrangement) of wood in a river system is fundamentally

\footnotetext{
${ }^{6}$ E-mail addresses: pjgvaz@isa.utl.pt

7 dana.warren@oregonstate.edu

8 eric.merten@wartburg.edu

9 christopher.robinson@eawag.ch

10 ppinto@uevora.pt

11 frego@isa.utl.pt
}

a product of the interaction between wood supply, transport, and retention characteristics of a river (Gurnell et al. 2002, Abbe and Montgomery 2003). These factors vary along the river continuum (Gurnell 2003) and among streamside forests. Therefore, stocks are expected to vary among streams of differing sizes within a watershed and between forest types. However, few investigators have considered source-to-sink aspects of wood in rivers (Arseneault et al. 2007) across a breadth of spatial scales, differing forest types, and stream sizes.

Fire is an important driver of wood recruitment to streams. It can kill trees or cause injuries that increase 
their susceptibility to windthrow and disease (Resh et al. 1988). Such trees are recruited more readily into fluvial systems (Spies et al. 1988, Benda et al. 2003). Studies on stream wood dynamics in the context of fire history have been focused on pristine regions or those with a single forest-management system, but rarely on landscapes with long legacies of land management or multiuse systems with production forests and agriculture. This landscape is common across Euro-Mediterranean countries, where $\sim 0.5$ million ha/y are burned by wildfires (Moreira et al. 2011). In Portugal, where we conducted our study, wildfires have burned $>30 \%$ of the land area since 1980 (Camia et al. 2008), and varying forest management activities have affected the characteristics of stream wood (Vaz et al. 2011).

Fire and forest management are important disturbances because they can influence both the amounts and organization of stream wood with boom-and-bust periods of recruitment to and transport in stream channels. Shortly after a fire, high inputs of wood to streams are expected because of tree mortality (Harmon et al. 1986, Benda and Sias 2003). However, during the postfire period of regrowth when inputs are low (Minshall et al. 1989), existing stream wood is redistributed and in-stream transport processes may dominate wood transfer from upstream to downstream reaches. Fluvial transport is greatest when the length of stream wood is shorter than the channel width (Lienkaemper and Swanson 1987, Nakamura and Swanson 1993). Thus, one might expect a greater degree of wood organization (i.e., nonrandom distribution) in larger streams where transport capacities are greater than in smaller streams where transport capacity is low (Kraft et al. 2011). Human activities also can affect amount, size, and organization of stream wood. In the short term, tree thinning can contribute many small, discarded pieces of wood that are readily moved by the river (Gurnell 2003), but in the long-term, forest management leads to changes in tree species composition and age structure with further consequences for the amount and size distribution of stream wood. Intended or unintended effects of management actions on the quantity and arrangement of stream wood are poorly understood (Nakamura and Swanson 2003), especially when coupled with the effect of wildfire in fire-prone landscapes.

We quantified the volume and organization (random, aggregated, segregated) of wood in 27 burned streams of central Portugal. Our study encompassed a range of stream sizes and adjacent land uses, including 3 common managed forest types in southern Europe. We quantified and compared stocks of stream wood across varying channel sizes and adjacent forest types to address 2 main objectives and associated hypotheses. Our $1^{\text {st }}$ objective was to assess the effects of forest type, stream size, and their interaction on volume of stream wood in Mediterranean-type ecosystems of southern Europe. We tested the hypothesis that a forest type $\times$ stream size interaction would be the primary factor accounting for volume of stream wood per unit area rather than a simple pattern of decreasing volume in a downstream direction independent of forest type. Our $2^{\text {nd }}$ objective was to assess the effects of forest type, stream size, and their interaction on organization of stream wood. Based on the expectation that transport capacity increases with increasing stream size, we tested the hypothesis that the organization of wood in the river network would show increased aggregation in a downstream direction independent of forest type.

\section{Methods}

\section{Study area and study design}

We conducted our study in east-central Portugal from October 2009 to August 2011 in subbasins of the Tagus River that experienced extensive wildfires between 2003 and 2007 (Fig. 1). Land cover in these subbasins is dominated by forests, shrublands, and agriculture. We selected 9 subbasins (mean drainage area $=59 \mathrm{~km}^{2}$, range $=26-143 \mathrm{~km}^{2}$ ) representing 3 dominant forest types: eucalyptus (Eucalyptus globulus), maritime pine (Pinus pinaster), and cork oak (Quercus suber). We used geographic information system processing of a $25-\mathrm{m}$ digital elevation data set and a 1:25,000-scale hydrography network to calculate subbasins and stream orders (Strahler 1957). Within each subbasin, we selected one $1^{\text {st }}$, $2^{\text {nd }}-$, and $3^{\text {rd }}$-order stream reach $(\sim 500 \mathrm{~m}$ each) representative of the general conditions in the subbasin. In total, we assessed 27 burned reaches comprising $\sim 13,460 \mathrm{~m}$ of stream channel.

The local climate is Mediterranean with hot, dry summers and cool, wet winters. Mean annual precipitation is $512 \mathrm{~mm}$ (range: $3 \mathrm{~mm}$ in July to $82 \mathrm{~mm}$ in November), and mean annual temperature is $15.8^{\circ} \mathrm{C}$ (range: $9^{\circ} \mathrm{C}$ in December-January to $23^{\circ} \mathrm{C}$ in July-August). The area has gentle slopes. The structure of burned areas of maritime pine (MP) was shrubby with dense growth of Erica spp., Cistus spp., and Ulex spp. and young postfire maritime pine. Sparse shrubs were present in the understory of postfire recovered stands of eucalyptus (EC). In contrast, cork oak (CO) stands usually had bare soil with some low understory grasses. Additional details are provided in Vaz et al. (2011). 


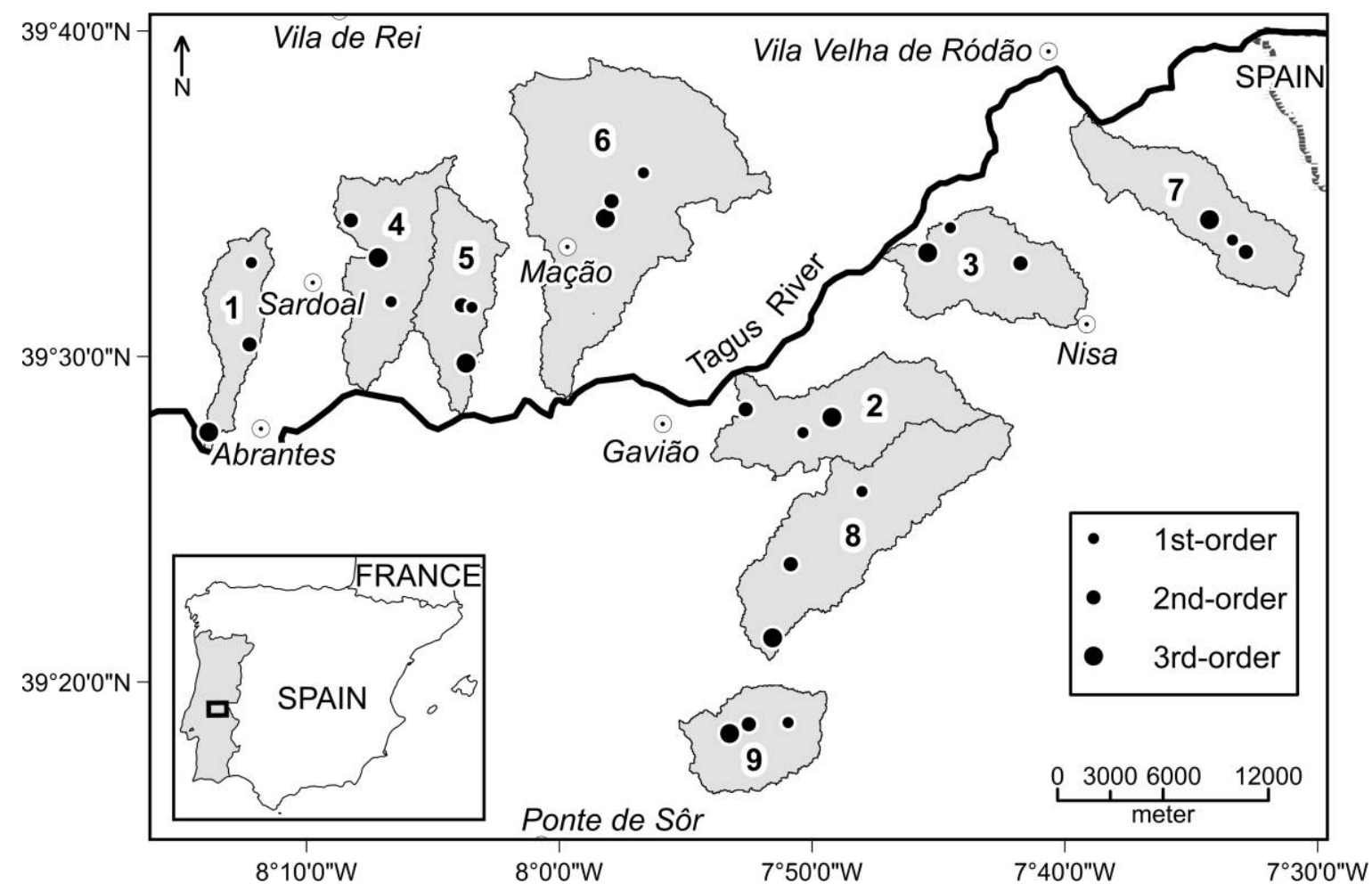

FIG. 1. Location of the 27 sampling sites in east-central Portugal within nine subbasins of the Tagus River. The subbasins were dominated by 3 forest types: eucalyptus (1-3), maritime pine (4-6), or cork oak (7-9). Within each subbasin, three 500-m stream reaches were assessed, one each from $1^{\text {st }}-, 2^{\text {nd }}-$, and $3^{\text {rd }}$-order streams.

\section{Forest and stream characterization}

$\mathrm{CO}$ stands are managed mostly by an agro-forestry system called montado (dehesa in Spain). CO trees occur irregularly at densities from 30 to 60 trees/ha and are harvested for cork every 9 to $12 \mathrm{y}$ without felling. Trees grow among pastures and cereal crops (Bugalho et al. 2011). CO trees in the region had a mean age of 20 to $40 \mathrm{y},>90 \%$ of the stands had a basal area $<10 \mathrm{~m}^{2} /$ ha, and $64 \%$ had $<50 \%$ crown cover (NFA 2010). Branch pruning for rehabilitation of burned $\mathrm{CO}$ trees is done on almost all trees. Slash from this activity produces wood 0.5 to $2 \mathrm{~m}$ long that eventually reaches streams where trees occur along the stream (Fig. 2A, B).

$\mathrm{MP}$ is grown for timber in monoculture stands with $\sim 235$ stems/ha. More than $50 \%$ of these stands were $<10$ y old ( $30 \%$ had irregular ages), $>75 \%$ had a basal area $<10 \mathrm{~m}^{2} / \mathrm{ha}$, and $>70 \%$ had $>50 \%$ crown cover area (NFA 2010). Intense wildfires kill most MP trees (especially younger trees), and the dead trees fall within 1 to 3 y (PV, personal observation). No postfire logging was done in the MP sites, and fire-killed trees were left on the ground on stream side slopes (Fig. 2C, D).

$\mathrm{EC}$ is planted in monocultures with $\sim 377$ stems/ha for paper pulp production. A substantial part of these stands had irregular ages ( $45 \%$ was $1-15$ y old) or was very young ( $22 \%$ was $<4$ y old), $>90 \%$ had a basal area $<10 \mathrm{~m}^{2} /$ ha, and $>90 \%$ had $>50 \%$ crown cover (NFA 2010). Rapid growth of EC allows rapid postfire recovery. Across EC systems, the intensity of human interventions following fire is variable. When these interventions exist, managers use a stumps-coppice method of regeneration for top-killed trees. The burned trees are cut and wood is removed to create a stump that will coppice. Slash (e.g., trunks, limbs) from this activity produces wood pieces 2 to $3 \mathrm{~m}$ long that can eventually reach streams (Fig. 2E, F).

Riparian zones $(0-15 \mathrm{~m}$ in width, with a distinct riparian community) were often present along streams in MP and EC forests, and their width increased with stream size. Uncultivated riparian vegetation was dominated by ash (Fraxinus angustifolia), alder (Alnus glatinosa), black poplar (Populus nigra), and willow (Salix atrocinerea, Salix alba, Salix salvifolia), and frequently was surrounded by edges of bramble-thicket (Rubus ulmifolius). In most southern areas, hawthorn (Crataegus monogyna) also was common. In addition to the indigenous species, silver wattle (Acacia dealbata), an exotic invasive and fire-prone tree, was widespread across the surveyed riparian zones (Silva et al. 2011). Trees from the adjacent forest often extended near $1^{\text {st }}$ order streams, but $3^{\text {rd }}$-order streams generally had a 

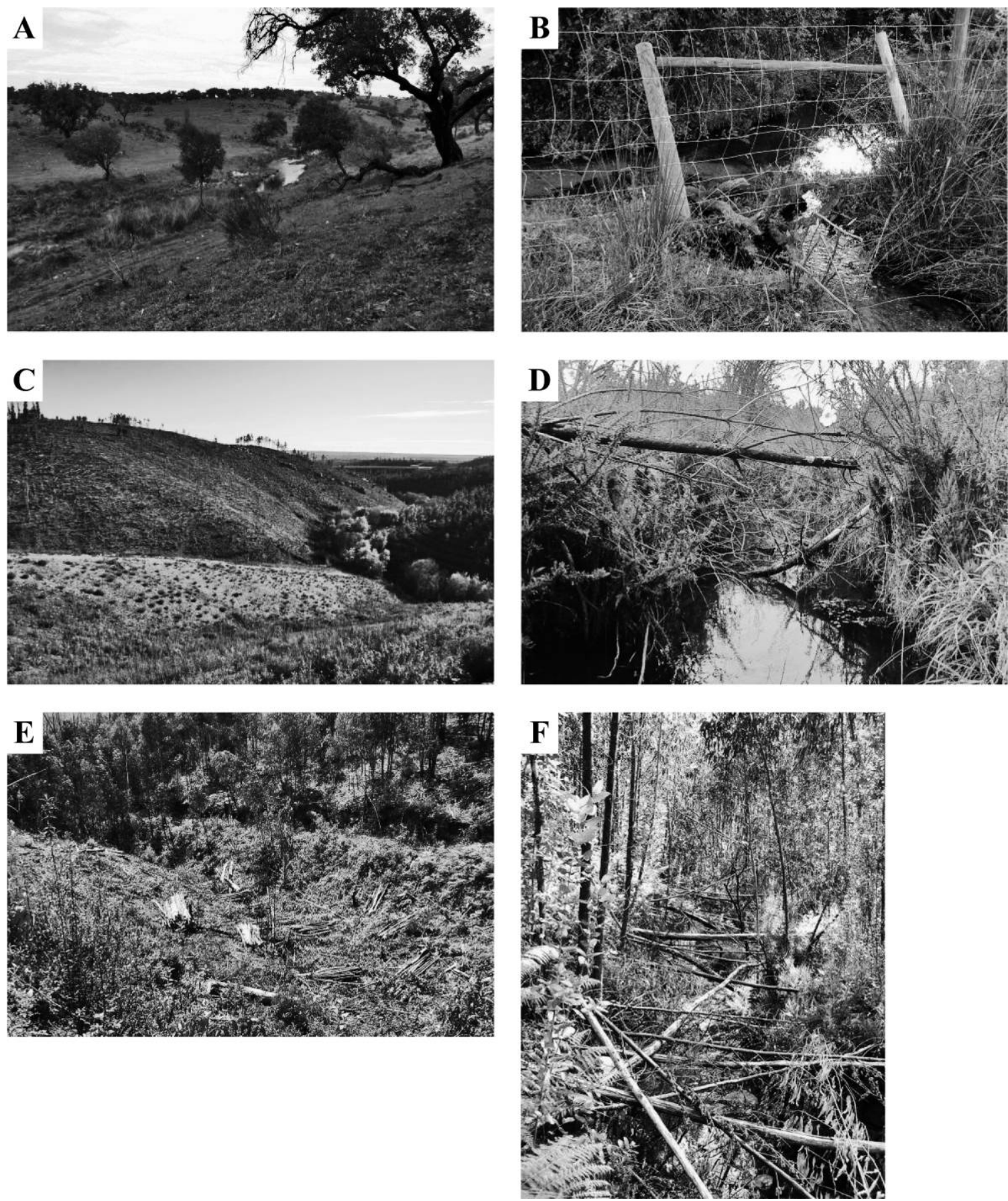

FIG. 2. Photographs of $1^{\text {st }}$ - to $3^{\text {rd }}$-order streams and riparian conditions in 2010 after the 2003-2007 wildfires in central Portugal. The streams flow through monospecific managed forests of cork oak (A, B), maritime pine (C, D), and eucalyptus (E, F).

distinct riparian community (Fig. 2C). Gaps $>10 \mathrm{~m}$ in the riparian community were common where trees of the managed forest species occurred directly along the stream margins. CO areas followed the same pattern of increasing riparian-zone width increasing with stream size, but generally had more limited riparian zones (Fig. 2A), and potential sources of large wood (adjacent forest or riparian species) could be absent for tens of meters.

Many of the streams in all 3 forest types were intermittent with stretches that remained dry for several months in a seasonal sequence of flooding and drought events. All $1^{\text {st }}$-order streams were intermittent, and flows were more continuous with increasing 
stream order and from CO to EC to MP streams. We often found woody vegetation and terrestrial plants in the channels and along the edges of intermittent streams (Fig. 2D). In $1^{\text {st }}$-order streams, terrestrial vegetation invaded the channel and sometimes extended for tens of meters. For example, dense entanglements of bramble-thicket were common obstructions across $1^{\text {st }}$ - and some $2^{\text {nd }}$-order streams. At the reach scale, mean channel widths were 1.34 to $12.75 \mathrm{~m}$, bed slopes were 0.02 to $7.80 \%$, and side slopes within $50 \mathrm{~m}$ of the stream were 0.80 to $18.27 \%$.

We observed removal of stream wood from some streams in the study subbasins, but outside of our study reaches. Signs of recent harvest were absent from the 27 reaches and respective riparian zones (evaluated by saw cuts on wood and piles of EC logs; see Fig. 2E). In $\mathrm{CO}$ forest, cattle fences, which can affect stream wood stocks and transport, were present downstream of 3 of the 9 study reaches (Fig. 2B). Overall, the intensity of postfire management across the 3 systems was higher at $\mathrm{CO}$ than EC and negligible at MP streams. In these 3 types of managed forest in central Portugal, wood enters streams by falling directly into the channel or as intended or unintended results of management actions. Wood on the floodplain also can float laterally into channels during floods or roll down eroding banks. Other mechanisms of lateral transport of wood, such as landslides, are negligible.

\section{Data collection}

Each study site included a 500-m reach where we measured downed pieces of wood (diameter $\geq$ $0.05 \mathrm{~m}$; length $\geq 0.5 \mathrm{~m}$ ) that were dead or alive but entirely uprooted. We excluded snags (Young et al. 2006), defined as pieces leaning or suspended over the stream at an angle $>30^{\circ}$. We measured all pieces that were accessible (10-20 pieces) in 3 wood jams (ranging from $>10$ to $<50$ pieces) found in 3 different reaches. We included only downed wood extending $>5 \%$ of the length of the piece within bankfull boundaries in the tallies.

One individual recorded all of the information for a piece of wood. We geo-referenced the position of each piece of wood along the reach at its center with a global positioning system (GPS) unit $(0.3-1 \mathrm{~m}$ precision by post-processing). The GPS reading was taken for 30 to $60 \mathrm{~s}$ and the average recorded then converted to a distance along the thalweg. We estimated the length $(\mathrm{m})$ of each piece to the nearest $20 \mathrm{~cm}$ for the segment of the piece that was $>1 \mathrm{~cm}$ in diameter. We measured length with a meter tape for pieces $>6 \mathrm{~m}$ long and estimated it for pieces $<6 \mathrm{~m}$ (verified by measurement for the first 20 pieces/reach). We estimated the diameter of each piece to the nearest $0.5 \mathrm{~cm}$ at a single point considered the mean diameter by visual assessment. We measured diameter with a meter tape for pieces $>15 \mathrm{~cm}$ diameter and estimated it for pieces $<15 \mathrm{~cm}$ diameter (verified for the first 20 pieces/reach). We assessed the burned status of each piece following Jones and Daniels (2008) during the field-data collection but later simplified the assessment to burned (bark or sapwood charred) or unburned. We identified tree type (MP, EC, CO, or riparian species) from morphological characteristics of the piece. We recorded the orientation of each piece to flow direction as $0^{\circ}$ (parallel), $90^{\circ}$ (perpendicular), or intermediate. Wood decay classes used were adapted from Jones and Daniels (2008) for field-data collection. EC bark usually comes off in fires, so we adapted the method and did not assess bark integrity as an attribute of decay for this species.

We measured channel widths every $10 \mathrm{~m}(\sim 51$ widths/reach) with a laser meter (precision: $1 \mathrm{~mm}$ ) and a target. We measured only unobstructed channel (width available to transport stream wood). We recorded the shorter of bankfull width or the distance across the stream between the innermost plant stems (diameter $\geq 0.03 \mathrm{~m}$ ) every $10 \mathrm{~m}$. We derived the wood length:channel width ratio for each piece of wood ( $\mathrm{L}^{*}$; length divided by nearest channel width).

We further characterized the following variables for each stream reach using GIS: 1) reach gradient (gradient $=$ ratio of vertical drop per unit of horizontal distance), 2) mean side slope (sslope) within $50 \mathrm{~m}$ on each side of the stream reach, 3) sinuosity (ratio of reach length to straight-line distance between reach ends), 4) year of the wildfire (fireyear $=2003,2005,2007$ ) affecting the stream reach, 5) drainage area (drainarea = side-slope drainage area [ha] of the stream reach), and 6) proportion of burned area within the drainage area (burnarea).

\section{Data analysis}

Binned neighbor-k analysis.-We quantified stream wood distribution with binned linear neighbor- $k$ analysis (Kraft et al. 2011). We coded the location of each piece of wood as the distance $(\mathrm{m})$ of the center of the piece from an initiation point along the thalweg. Thus, the collective arrangement of wood in a reach was presented as a series of numbers with values from 0 to 500 that corresponded to wood location along the reach relative to the initiation point. Next, the pieces of wood within set distance intervals $(10-\mathrm{m}$ bins) from a focal piece of wood were counted; i.e., the 
number of pieces within 0 to $10 \mathrm{~m}$ of the focal piece, within 11 to $20 \mathrm{~m}, 21$ to $30 \mathrm{~m}, 31$ to $40 \mathrm{~m}$, and so on. This process was repeated for each piece of wood in the reach until the number of wood pieces occurring at each interval distance from each piece of wood had been counted. Hence, this analysis produces a histogram of the collective number of wood pieces at a given distance from any other piece as defined by binned distance intervals. This histogram (the number of pieces within each interval for our observed wood distribution) was compared to a histogram produced by the same process applied to 1000 random arrangements of wood (a series of random numbers between 0 and 500 equal to the number of pieces of wood in the reach and chosen with replacement) along a stream reach. The collective numbers of wood pieces occurring in each distance interval bin $(0-10 \mathrm{~m}$, 11-20 m, 21-30 m, etc.) for each of the 1000 randomized wood distributions were ranked, and the results from our observed data were compared to the ranked values.

We considered wood significantly aggregated at a particular distance interval if the observed number of wood pieces in that distance-interval bin was $>975^{\text {th }}$ ranked number of pieces of wood from the 1000 randomizations in that bin. In other words, more wood occurred in that distance interval than would be expected by chance alone. We considered wood to be significantly segregated if the observed number of wood pieces in that distance-interval bin was $<25^{\text {th }}$ ranked number of pieces of wood from the 1000 randomizations in that bin. That is, less wood occurred in that bin than would be expected by chance alone. The $25^{\text {th }}$ and $975^{\text {th }}$ rank thresholds correspond to the 0.025 proportion of a normal distribution that would collectively represent $p=0.05$ in a 2-tailed test (Kraft and Warren 2003, Kraft et al. 2011).

This measure of distribution carries potential bias associated with wood occurring at the ends of the reach (Kraft et al. 2011). Only wood pieces near the ends of the reach (upstream or downstream) can occur at distance intervals that extend the full length of the reach. For example, many wood pieces could occur within $50 \mathrm{~m}$ or $100 \mathrm{~m}$ of another piece, but only a few pieces could occur within $450 \mathrm{~m}$ of another piece of wood. To correct this bias, we considered only bin distances $\leq 1 / 2$ the total reach length $(250 \mathrm{~m}$, 25 bins). This correction does not cut the reach in half in regard to which wood is counted. All wood is included in the analysis, but the results are evaluated only over bin intervals that collectively added up to $1 / 2$ the length of the stream. This correction caused the final bin in the series to include all distance intervals
$>240 \mathrm{~m}$ (up to $500 \mathrm{~m}$ ). Thus, these larger distances were included but were grouped into a single bin to address the low number of occurrences. Greater detail on this analysis and terms are given by Kraft and Warren (2003) and Kraft et al. (2011).

Results from the binned neighbor- $k$ analysis allowed us to assess whether the arrangement of wood was consistent with a random distribution or differed from what we would expect if wood were randomly arranged in a stream for each 10-m distance interval. We also were able to evaluate the number of bin intervals within the entire reach (of the 25 total bins) that showed significant aggregation, which would reflect increased wood accumulation (at variable intervals) along a stream. Conversely, the number of bins showing significant segregation would reflect increased transport capacity or decreased wood recruitment at regular intervals along a stream. We grouped significant aggregation and significant segregation into a broader category that we called wood organization within a stream (see Kraft et al. 2011 for greater detail on these metrics). We used the number of bins exhibiting these measures of organization (i.e., nonrandom wood arrangement along a reach) to compare patterns of wood distribution among reaches relative to stream and riparian-forest characteristics.

\section{Stream wood volume and organization}

We derived volume $(V)$ of individual wood pieces from the equation $V=\pi r^{2} L$, where $r$ is the radius and $L$ is the length. To derive volume per area at the reach scale, we summed the volumes of individual pieces $\left(\mathrm{m}^{3}\right)$ and then divided by the reach area (ha). We summed volumes by species separately by reach to assess patterns in species of stream wood (adjacent managed-forest species vs riparian species).

We evaluated the effects of forest type (foresttype), stream order (order), and order $\times$ foresttype interaction on wood volume/ha (volume) and wood organization (organization). We also tested the effects on volume and organization of the covariatesgradient, sslope, sinuosity, fireyear, drainarea, burnarea, and proportion of burned pieces (burnwood). Each variable was expressed per stream reach $(n=27)$. A matrix of Spearman's correlations for initial explanatory variables revealed that order was significantly correlated with gradient $(r=-0.489, p<0.01)$, sinuosity $(r=0.600, p<0.01)$, drainarea $(r=0.629$, $p<0.01)$, and burnwood $(r=0.566, p<0.01)$. Correlation coefficients between the remaining variables used in the model (order, foresttype, sslope, fireyear, and burnarea) were all $<|0.30|$, indicating no collinearity problems. 
Groups of 3 stream reaches (orders 1, 2, and 3) were nested within a subbasin ( 3 subbasins per foresttype: $\mathrm{CO}, \mathrm{EC}, \mathrm{MP})$, so we used mixed-effects models for the analysis of volume and organization, with subbasin as a random factor. Before analysis, we $\log (x)$-transformed sslope and $\arcsin (x)$-transformed burnarea to satisfy assumptions of normality. We treated fireyear as factorial with 3 levels $(2003,2005,2007)$ and centered sslope and burnarea when building the models. We did all tests in R (R Development Core Team, Vienna, Austria).

The 2 components for modeling were tests for effects on volume and for effects on organization. We $\log (x)$-transformed volume to satisfy assumptions of normality. After comparing the linear regression model with the linear mixed-effects model (LMM) with the random intercept for subbasin, we chose the $\operatorname{LMM}(L=4.13, \mathrm{df}=1, p=0.021)$ and used the nlme package in $R$ (Pinheiro et al. 2011) to fit LMM. We modeled counts of organized $10-\mathrm{m}$ bins per reach with generalized linear mixed-effects models (GLMMs). The response variable was expressed as a count, so we used a Poisson GLMM. We ran 3 models: one applied to the total number of organized bins per reach (no. segregated + no. aggregated), and 2 separate models for the number of aggregated or segregated bins/stream reach. We used the lme4 package (Bates et al. 2011) to fit GLMM.

For both components of the analysis, we started with a model with all 5 variables (order, foresttype, sslope, fireyear, and burnarea) and the order $x$ foresttype interaction in the fixed part of the model. We used backward elimination of variables (Zuur et al. 2009) to remove each main term in turn, and then applied the likelihood ratio test of nested models. We calculated variance inflation factors (VIF) for the full set of explanatory variables to detect eventual collinearity (VIF $>5$ ). We evaluated model adequacy by plotting residuals vs fitted values and explanatory variables and model fit by the proportion of the null deviance explained. We applied post hoc tests (Tukey contrasts for multiple comparisons of means [MCM]) to final models to investigate which effects were different from each other (multcomp package; Hothorn et al. 2008).

\section{Results}

Stream wood frequencies, volumes, orientations, and decay

We measured 1483 pieces of wood $($ mean $=70 \%$ burned/reach), whose frequencies and volumes were distributed as shown in Table 1 . Mean volume was $\geq 1 / 3$ lower in CO streams than in EC or MP streams. Only $8 \%$ of the volume in $\mathrm{CO}$ streams came from the managed forest type species. This value was 4 and $6 \times$ lower than in MP and EC streams, respectively. Percent contribution from the managed forest type for total volumes (Fig. 3A) was lowest in $3^{\text {rd }}$-order streams and highest in $1^{\text {st }}$-order $\mathrm{CO}$ and EC streams. $\mathrm{L}^{*}$ were distributed as shown in Fig. 3B. Stream wood decay was generally high (Table 2 ).

EC $1^{\text {st }}$-order streams had the greatest proportion of wood oriented at intermediate angles to the flow (Fig. 4A). More stream wood was oriented parallel to the flow in larger than in smaller streams (Fig. 4B). The number of pieces oriented perpendicular to flow was similar among stream sizes.

\section{Effects on volume}

Foresttype, order, and the foresttype $\times$ order interaction were the best predictors of volume. Thus, the effect of stream size on volume of wood per area was not the same for all foresttypes. During the model selection process fireyear, sslope, and burnarea were sequentially dropped. The resulting model $\left(R^{2}=0.545\right)$ is shown in Table 3.

Volume did not differ among foresttypes or orders (F-test with anova command in nlme; $p>0.1$ ), but the order $\times$ foresttype interaction was significant $\left(F_{4,12}=\right.$ $4.261, p=0.022$; Fig. 5). Fitted values for MP streams were higher than values for CO streams (MCM, $Z=$ $2.752, p=0.032$ ) and did not differ from values for $\mathrm{EC}$ streams $(p>0.1)$. Volume tended to be higher in EC than in CO streams $(Z=2.55, p=0.056)$. Comparing volume between pairs of stream orders revealed no significant differences. We did not test to see which order $\times$ foresttype combinations differed, but instead assumed that confidence intervals that did not overlap in Fig. 5 represented significantly different mean volumes. The pattern clearly differed between $\mathrm{CO}$ and EC or MP (Fig. 5). Unlike the pattern in MP and EC, $1^{\text {st }}$-order $\mathrm{CO}$ streams had significantly less volume than $2^{\text {nd }}$ - or $3^{\text {rd }}$-order CO streams. Only MP streams had our hypothesized pattern of decreasing volume per unit area from $1^{\text {st }}$ - to $3^{\text {rd }}$-order.

\section{Effects on organization}

Number of organized bins.-The optimal GLMM showed that foresttype and order were the best predictors of the number of organized bins. Sslope also had a nonsignificant positive effect on organization (Table 4 ). The foresttype $\times$ order interaction, burnarea and fireyear were not significant and were dropped sequentially. Wood in $\mathrm{CO}$ streams was significantly more organized (more bin intervals that were significantly aggregated or segregated) than wood in MP streams (MCM, $Z=-2.900, p=0.010)$. 


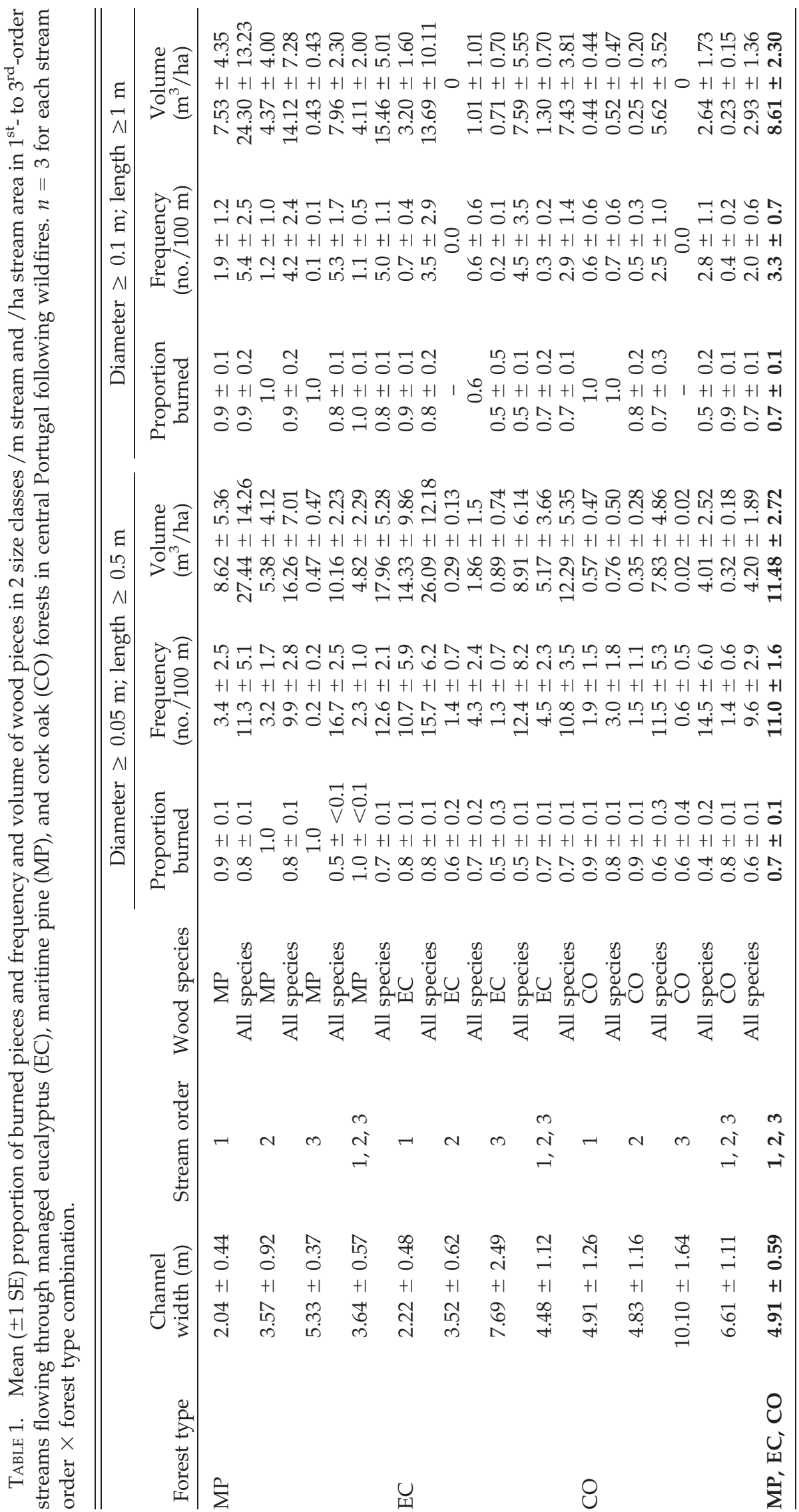



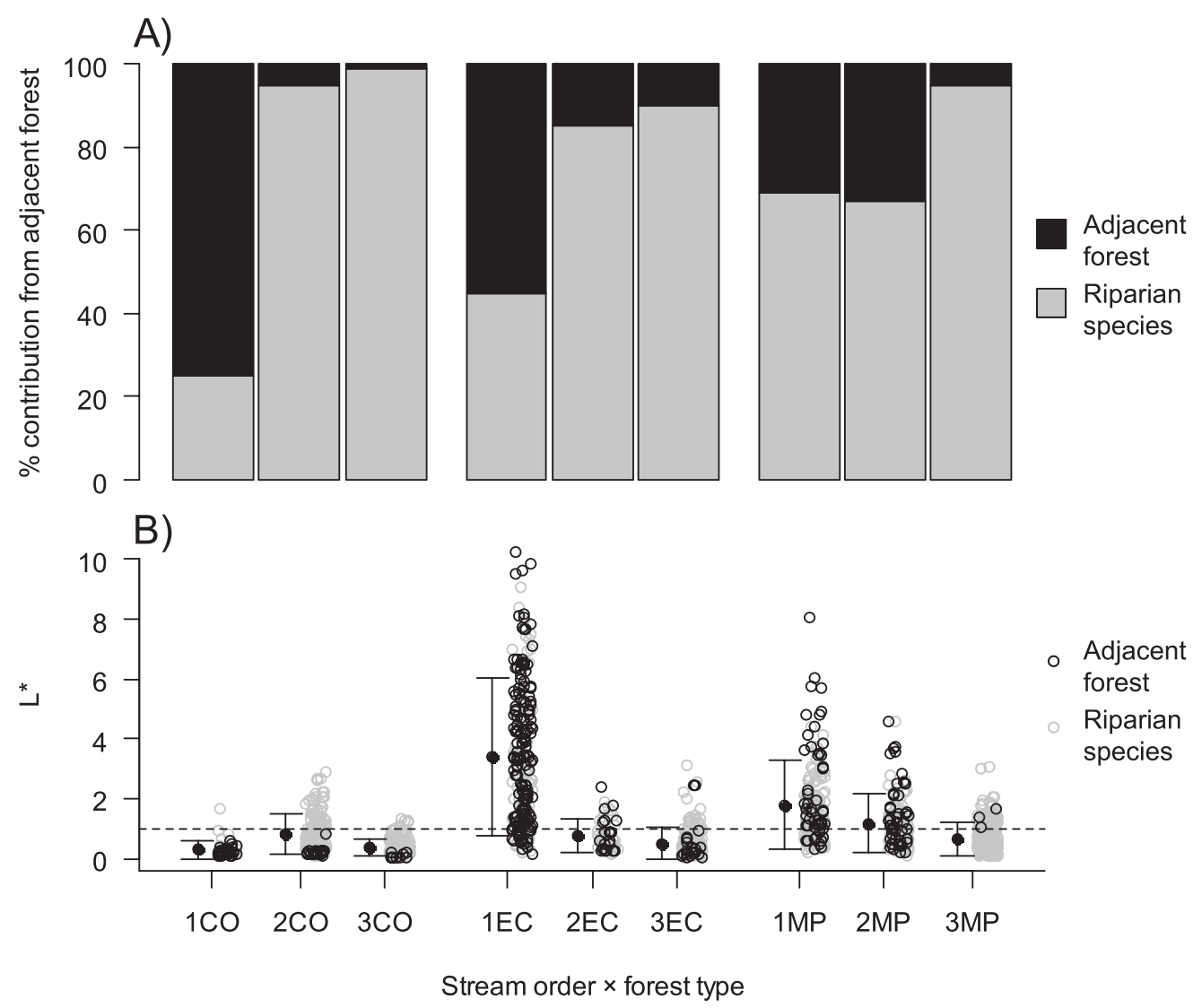

FIG. 3. Mean ( $\pm 95 \% \mathrm{CI}) \%$ contribution of the tree species in the adjacent managed forest to the total volume of stream wood $(\mathrm{A})$, and wood length:channel width ratios $\left(\mathrm{L}^{*}\right)(\mathrm{B}) . n=3$ stream reaches surveyed $(\sim 500-\mathrm{m}$ each) within each stream order $\times$ forest type combination (coded as order.forest type). Streams are $1^{\text {st }}, 2^{\text {nd }}-$, or $3^{\text {rd }}$-order. Forest types are cork oak (CO), eucalyptus (EC), or maritime pine (MP). The horizontal dashed line in (B) indicates a ratio of 1.

Wood tended to be more organized in CO than in EC streams $(Z=-2.101, p=0.086)$. Organization did not differ between MP and EC streams $(p>0.1)$. Organization was greater in $1^{\text {st }}$ than in $3^{\text {rd }}$-order streams $(Z=-2.809, p=0.013)$, but organization in $2^{\text {nd }}$-order streams did not differ from that in $1^{\text {st }}$ - or $3^{\text {rd }}$-order streams (Fig. 6A).

Models for aggregation and segregation evaluated separately were similar. In both cases the sslope term was dropped and the foresttype $\times$ order interaction remained, indicating that effects of stream size differed among foresttypes (Table 4). CO streams had fewer aggregated bins than EC streams ( $Z=$ $2.737, p=0.031$ ), probably because of a difference in the number of bins with significant aggregation in EC $1^{\text {st }}$-order streams (Fig. 6B). CO streams had an increase of wood aggregation from $1^{\text {st }}$ - to $3^{\text {rd }}$-order streams. CO streams had more segregated bins than EC streams $(Z=-2.984, p=0.016)$. First-order streams had more segregated bins than did $3^{\text {rd }}$-order streams $(Z=-3.464, p=0.003)$.Within $\mathrm{CO}$ and MP foresttypes, the number of segregated bins was higher in $1^{\text {st }}$ - than in $3^{\text {rd }}$-order streams.

\section{Discussion}

\section{Across-system variability}

Wood volume per area and distribution patterns differed among forest types. CO streams had the least wood, but in the most organized pattern, a result reflecting either lower inputs or greater mobility of wood. Only CO streams had the expected pattern of increasing aggregation with increasing stream size, a result that suggests a higher mobility of stream wood in $\mathrm{CO}$ than in other stream types. The highest contrast in wood volume was between CO and MP. MP streams had more wood in a less organized pattern of distribution. Both systems shared a clear decreasing trend of segregated areas (with less wood than expected by chance) from $1^{\text {st }}$ - to $3^{\text {rd }}$-order streams. EC streams were intermediate between $\mathrm{CO}$ and MP streams, but were more similar to MP than to $\mathrm{CO}$ 
TABLE 2. Decay classes of wood pieces in streams with counts and percentages by forest type. Decay classes were adapted from Jones and Daniels (2008). Classes 1 and 2 were merged. Forest types were cork oak (CO), eucalyptus (EC), and maritime pine (MP).

\begin{tabular}{lccc}
\hline \hline & \multicolumn{3}{c}{ Decay class } \\
\cline { 2 - 4 } \multicolumn{1}{c}{ Forest type } & 1 and 2 & 3 & 4 \\
\hline CO & $28(7 \%)$ & $177(41 \%)$ & $229(53 \%)$ \\
EC & $25(5 \%)$ & $237(49 \%)$ & $225(46 \%)$ \\
MP & $107(19 \%)$ & $233(41 \%)$ & $222(40 \%)$ \\
Total across forests & $160(11 \%)$ & $647(44 \%)$ & $676(46 \%)$ \\
\hline
\end{tabular}

streams in regard to volume, organization, and aggregation/segregation. EC streams differed from $\mathrm{CO}$ and MP streams by having the most complex patterns of volume and organization across stream sizes and the highest dispersion for their fitted values.

\section{Drivers of across-systems variability}

Volume and organization were not affected by side slope, burn year, or proportion of the drainage area burned. Below, we discuss 4 potential drivers of across-system variability: vegetation obstructions, $L^{*}$, management actions, and fire effects.

Within-channel vegetation obstructions and $L^{*}$.-Withinchannel living woody vegetation traps and hinders transport of stream wood. The patterns of segregation in $\mathrm{CO}$ and $\mathrm{MP}$ (decreasing from $1^{\text {st }}$ - to $3^{\text {rd }}$-order streams) were consistent with our field observations. Wood segregation was more common in streams with more woody vegetation growing in the channel, particularly in channels with intermittent flow. We recommend quantifying within-channel extensions of terrestrial vegetation in future studies of wood dynamics in intermittent streams.

$\mathrm{L}^{*}$ is recognized as a primary control on stream wood stability (Haga et al. 2002, Abbe and Montgomery 2003, Cadol and Wohl 2010, Merten et al. 2010, 2011) and can be considered in conjunction with organization when evaluating the probable interaction between input and transport in a stream (Kraft et al. 2011). Within CO streams, mean $L^{*}<1$ favored transport-based control (Swanson 2003) of wood distribution, an interpretation that also is suggested

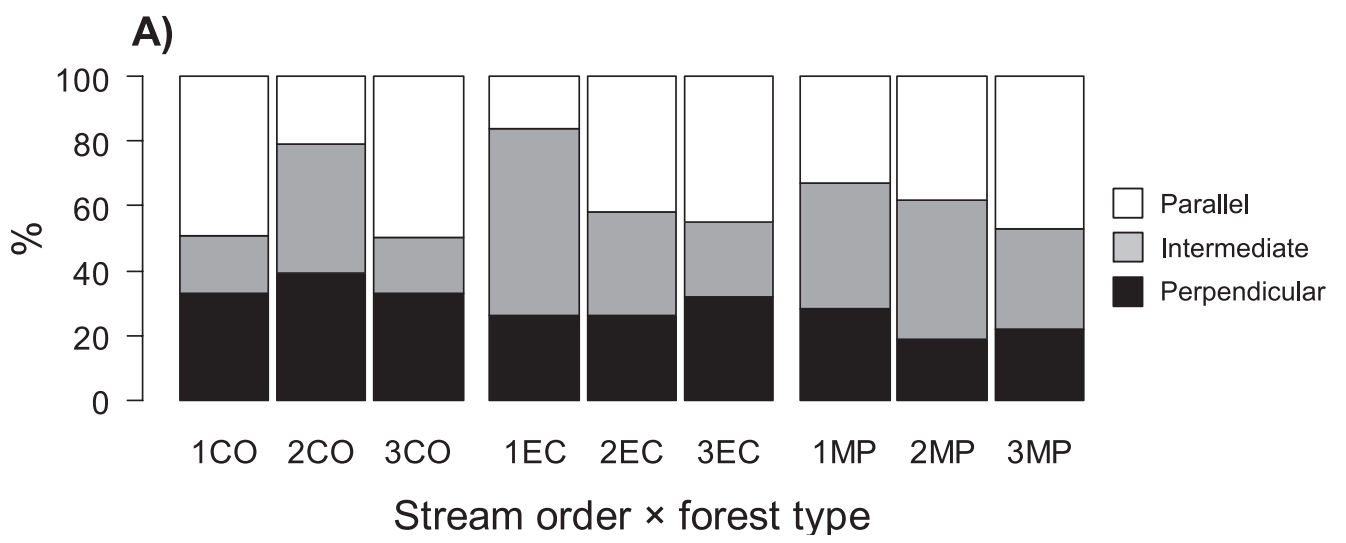

B)

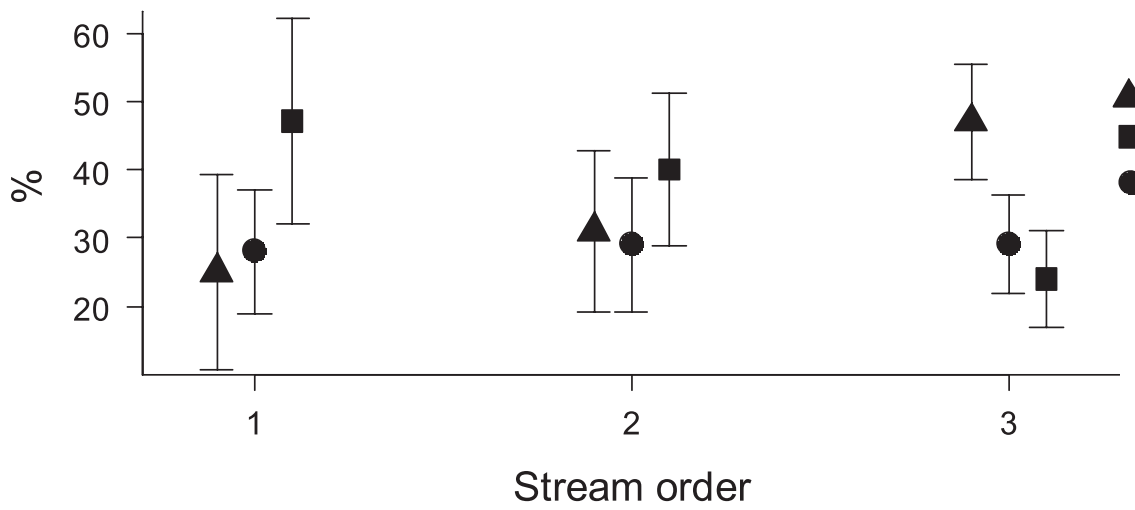

FIG. 4. Mean percentages of alignments of stream wood by stream order $\times$ forest type combinations (A) and by stream order (B). See Fig. 3 for codes. The alignment of each wood piece refers to the angle relative to flow direction: perpendicular $=90^{\circ}$, intermediate $=$ other angles, parallel $=0^{\circ}$. Error bars are $95 \%$ confidence intervals. 
TABLE 3. The fixed part of the optimal linear mixed-effects model predicting volume of stream wood following wildfires in central Portugal. Main effects are forest type $(\mathrm{EC}=$ eucalyptus, $\mathrm{MP}=$ maritime pine $)$ and stream order $(2,3)$. SE $=$ standard error, VIF $=$ variance inflation factor.

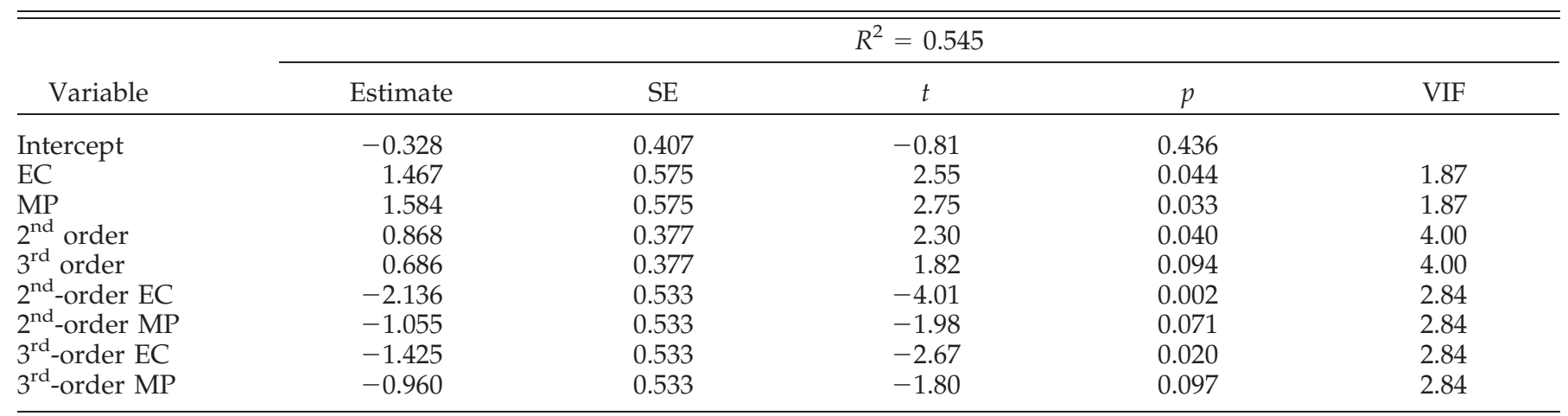

by increasing aggregation with increasing stream size. In contrast, in smaller streams in timber-production forests $(E C, M P)$, especially $1^{\text {st }}$-order EC streams, $L^{*}>1$ favored organization dominated by input processes rather than transport. Wood orientation affects its exposure to hydraulic forces (Merten et al. 2010) and, thus, its propensity for transport. The high proportion of wood oriented at intermediate angles in $1^{\text {st }}$-order EC streams reinforced their input-based dynamics. The high proportion of wood oriented parallel to flow in larger streams suggested repositioning by fluvial forces. The proportion of wood oriented perpendicular

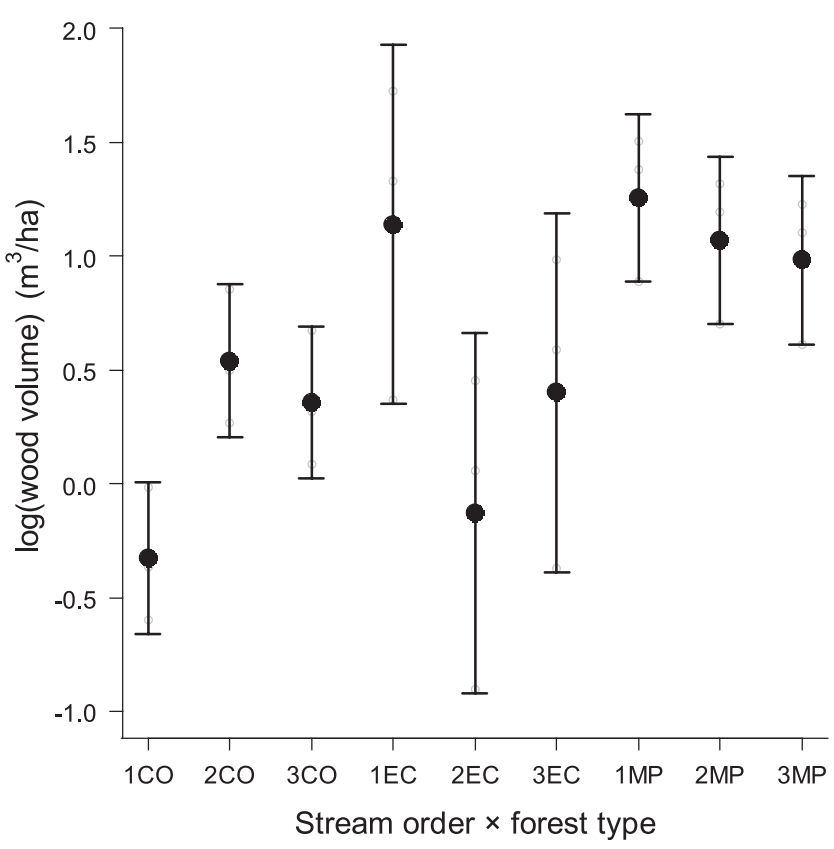

FIG. 5. Mean $( \pm 95 \% \mathrm{CI})$ fitted values for the optimal mixed-effects model predicting volumes of stream wood by stream order $\times$ forest type combination. See Fig. 3 for codes. to the flow was constant across stream sizes. These pieces may not have been transported yet.

Management and effects of fire.-Human activities influenced the kinds of wood input in $\mathrm{CO}$ and EC. In $\mathrm{CO}$, branch pruning and salvage logging reduced wood input, and mostly smaller pieces of wood $\left(\mathrm{L}^{*}<1\right)$ entered streams (Vaz et al. 2011). In CO streams, obstruction of flow by vegetation favored segregation of wood in some reaches, whereas management in other reaches promoted $\mathrm{L}^{*}<1$ and, thus, transport and aggregation. For instance, $1^{\text {st }}$-order $\mathrm{CO}$ streams had the lowest volumes per stream area and the highest organization of stream wood. Thus, vegetation obstructions and management probably were the main drivers of the unexpected values for this stream size. Because of their limited riparian zones and low side slopes, $1^{\text {st }}$-order CO streams also were more exposed to external disturbances (e.g., stream wood removal, forest roads, mechanical cutting) than larger $\mathrm{CO}$ streams.

A wider range of intensity of human activity, varying from postfire abandonment (similar to MP) to active management near streams (similar to $\mathrm{CO}$ ) occurred in EC streams. Unlike in CO systems, where management activities were consistent, postfire management actions in EC forests varied across the region and probably yielded different effects on stream wood (see Thomas et al. 2000). Over the long term, stream clearing and clearcutting in EC stands caused depletion of stream wood and reduced wood inputs. The variability of management situations between EC systems is reflected in the lack of pattern in wood volume per stream area or organization and the greater dispersion of values across stream sizes.

Forest management affects the amount and size of wood in a river. In general, forest management, especially riparian logging, reduces total stream wood storage and increases wood mobility (Gurnell 2003, 
TABLE 4. The fixed portion of the 3 optimal generalized mixed-effects models predicting the number of 10-m bins with wood abundances suggesting an organized (nonrandom) distribution pattern. The $1^{\text {st }}$ model includes the total number of organized bins as the response variable. The $2^{\text {nd }}$ and $3^{\text {rd }}$ models include the number of aggregated or segregated (wood absence) bins, respectively, as response variables. Main effects are forest type (EC = eucalyptus, $\mathrm{MP}=$ maritime pine), stream order $(2,3)$, and sslope (side slope for side bands of $50 \mathrm{~m}$ on stream reaches). VIF = variance inflation factors. Underlined values indicate the $\%$ deviance explained.

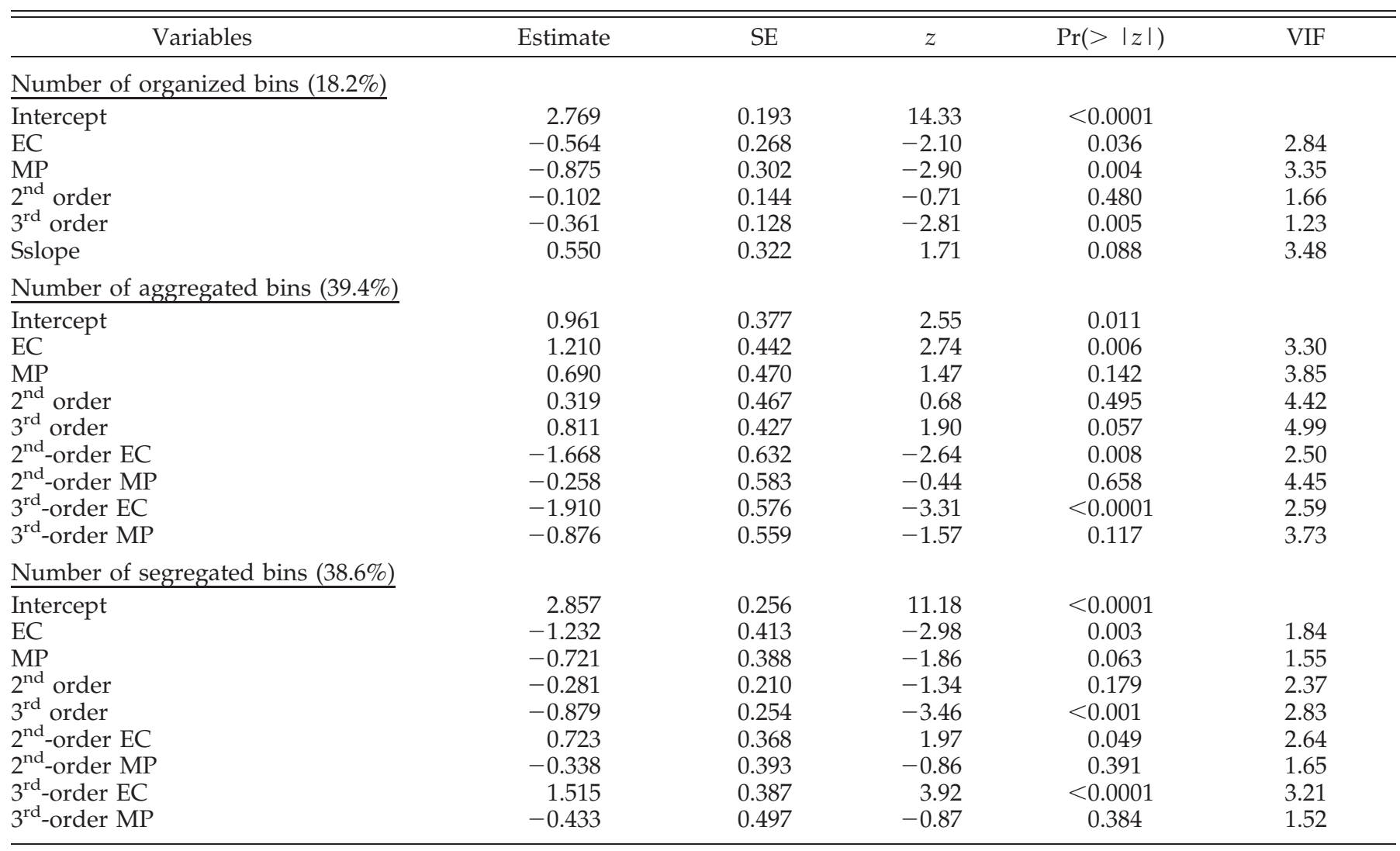

Mellina and Hinch 2009). However, this generalization was not applicable under the complex forestry scenarios we examined. We assumed that forest management in our systems would lead to straightforward reductions in wood recruitment with associated increases in wood movement and subsequent wood organization. However, wood dynamics are not that simple in our study systems, and we found important interactions between managed forest type and stream size. If hydraulic processes associated with stream size dominated wood dynamics, stream order but not forest type should have been significant in our models. However, forest management and postfire activities differed among the 3 forest types and, to some degree, among stream sizes. These differences led to different wood input rates and different wood characteristics (Vaz et al. 2011) and, thus, to variability in total wood volume and movement potential among stream sizes within a forest type. Euro-Mediterranean forestry is best understood from a total-human-ecosystem perspective
(Naveh and Lieberman 1984), where singlespecies stands are often characterized by different silviculture practices. Thus, stream-size $\times$ forest-type interactions are key factors affecting stream wood dynamics.

The legacy of the 2003-2007 wildfires was highlighted by our finding that $70 \%$ of stream wood per reach was burnt. Burned stream wood is straighter, has fewer branches, is more decayed, and is larger than unburned wood in these systems (Vaz et al. 2011). Over time, these differences are likely to become more pronounced, except that stream wood should become smaller because of decay and breakage (Hassan et al. 2005). Decay rates of stream wood should be greater in our study systems than in systems where stream wood remains waterlogged because stream drying in summer exposes wood to aerobic conditions in this region (Suberkropp 1998). During wet periods, hydraulic forces also may break or abrade weakened burned wood into smaller transportable pieces. We expect burned stream wood 


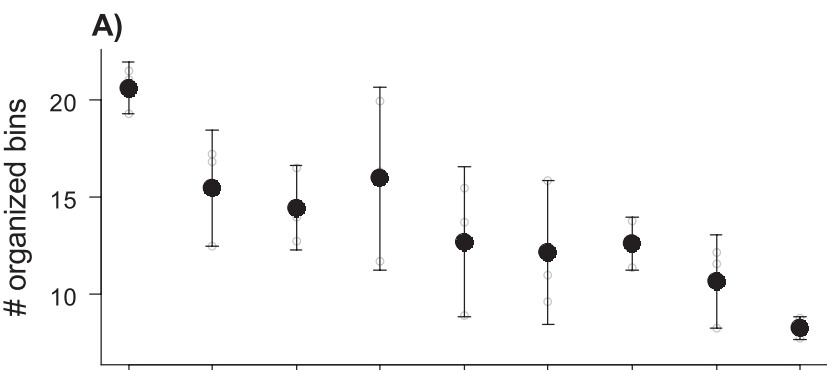

B)

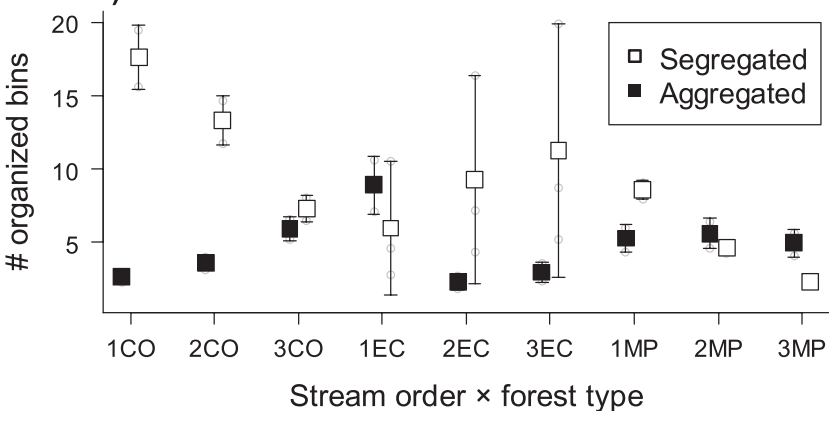

FIG. 6. Mean $( \pm 95 \% \mathrm{CI})$ fitted values for the optimal mixed-effects models predicting the number of $10-\mathrm{m}$ bins having stream wood in an organized (nonrandom) distribution pattern (A) and number of bins having aggregated or segregated distributions (B).

volume to decrease as future inputs diminish. Smaller pieces will then be governed by greater transport, leading to increasing organization of burned wood distributions. The overall structure of stream wood is strongly influenced by wildfire, but the effect may be obscured by among-system variability in species characteristics and management (Vaz et al. 2011).

Little research has addressed effects of wildfire on the organization of wood in streams despite the important effect of fire on forest cover and, thus, wood input, mobility, and distribution (Marcus et al. 2011). Our prediction that the organization of stream wood will reflect its increased mobility over time is in line with results of previous studies. Minshall et al. (1997) reported that 2 to $5 \times$ more stream wood than usual moved in burned $1^{\text {st }}$ - to $3^{\text {rd }}$-order streams after fires in Yellowstone National Park. Young (1994) found that wood was more likely to move in a watershed that burned in 1988 than in an unburned watershed. This finding was confirmed $11 \mathrm{y}$ after the fires by Zelt and Wohl (2004). Additional research is needed to fully test our prediction.

\section{Low quantities of stream wood}

Compared to values reported in literature reviews of wood in unmanaged river corridors (Gurnell 2003) and in catchments highly modified by human activities (Elosegi and Johnson 2003), the volumes of stream wood in our study systems are extremely low. Volumes in our study streams are similar to the lowest values published by Gregory et al. (1993) for the Lymington River basin (0.6-50 $\left.\mathrm{m}^{3} / \mathrm{ha}\right)$ and Richmond and Fausch (1995) for streams in a harvested forest in the Rocky Mountains, USA (12.0-147 $\left.\mathrm{m}^{3} / \mathrm{ha}\right)$. Volumes reported by Hauer (1989) for streams in a mixed landuse catchment recovering from discharges from nuclear reactors in South Carolina, USA $\left(2 \mathrm{~m}^{3} / \mathrm{ha}\right)$ are of the same magnitude as those in $\mathrm{CO}$ streams $\left(2.93 \mathrm{~m}^{3} / \mathrm{ha}\right)$. Stream wood volumes in the Agüera basin in northern Spain (Diez et al. 2001) are much greater than volumes in central Portugal. Even the values reported by Diez et al. (2001) for $1^{\text {st }}$-order agricultural streams $\left(2 \mathrm{~m}^{3} / \mathrm{ha}\right)$ are greater than the volumes in our $1^{\text {st }}$-order $\mathrm{CO}$ agro-forestry systems $\left(0.76 \mathrm{~m}^{3} / \mathrm{ha}\right)$. Frequent disturbance by fire and forest management might be the cause of the exceptionally low volumes in east-central Portugal. These disturbances favor the presence of young riparian trees with small diameters (mean diameter of stream wood in our study was $9 \mathrm{~cm}$; PV, unpublished data).

\section{Looking ahead}

Patterns in stream wood stocks still reflect the 20032007 wildfires and are likely to retain a strong fire signal for years to come. After the 1988 Yellowstone fires, Romme et al. (2011) noted that stream wood recruitment reached its maximum 20 y postfire in smaller streams, wood patterns varied with stream size, and depletion of wood differed from stream to stream. In our study, the volume of stream wood is still dominated by burned wood and organization is low, results suggesting that the current arrangement of wood is largely a product of input dynamics rather than transport processes. We expect a similar pattern of future postfire stream wood that varies with stream size, but with high across-system variability. Conversely, most fire-killed snags in the riparian zone of our streams were in advanced decay and are likely to fall soon (PV, personal observation), an observation suggesting that peak wood inputs associated with the 2003-2007 fires are likely to occur sooner than $20 \mathrm{y}$ postfire. We expect burned stream wood to disappear soon because of rapid breakdown and decay, even though transport is limited. Overall, burnt stream wood probably is more ephemeral in Euro-Mediterranean intermittent streams than elsewhere.

Wildfires are natural in the Euro-Mediterranean region, and the ability to recover to a prefire state is quite high in burned forests of CO and EC (and even $\mathrm{MP})$. However, several studies suggest a decrease in 
forest resilience as higher frequencies of wildfires and droughts (Acácio et al. 2009) change areas from forests to shrubland (Díaz-Delgado et al. 2002, Acácio et al. 2007). In the Mediterranean Basin, these landscape changes have been accompanied by abandonment of land by people (see Sluiter and Jong 2007). As a consequence, many previous production forests that burned are now shrubland dominated by species that naturally resprout following fire (Pausas 1999). Under this scenario of shrubland expansion, the contribution of adjacent forest types to stream wood loadings should decline (a prediction that is in line with our low values) and wood inputs should become more dependent on riparian communities.

Dynamics of stream wood in Mediterranean Basin streams will be strongly influenced by future climate conditions. Projections indicate that fires will become increasingly frequent in the coming decades because of changing global climate and anthropogenic activities (Moriondo et al. 2006, IPCC 2007, Flannigan et al. 2009). Stream flows have decreased in the last $40 \mathrm{y}$ in southern Europe (Stahl et al. 2010). On the Iberian Peninsula, the decrease in stream flow is likely to accelerate in the coming decades because climate projections show a decrease in precipitation and more evapotranspiration induced by higher temperatures (Lorenzo-Lacruz et al. 2012). As stream flows decrease, upland plants will encroach on the channel (see Santos 2010), and stream energy to mobilize, export, and organize wood will decline. Plants will have greater access to water in the hyporheic zone of the stream. Reductions of water in the hyporheic zone can cause major shifts in hydrological dynamics (Huxman et al. 2005), including greater frequency of intermittent flows. Overall, shrubland encroachment probably will promote the absence of large wood over large areas of stream ecosystems. Habitats in such streams are particularly sensitive to changes in stream wood loading, and the full implications of reduced amounts of stream wood are unknown but potentially far-reaching for many taxa and life stages of aquatic organisms (Dolloff and Warren 2003). In small, drought-prone streams, such as those in CO forests, large wood may provide the only refuge during low flows, making stream wood particularly important to stream biota in the years to come.

\section{Acknowledgements}

PV was funded by the Portuguese Foundation for Science and Technology (FCT) (SFRH/BD/45490/ 2008). We thank the Dias family (Isidro, Elisa, Susana) for logistic support and accommodation, and João Jorge for help during fieldwork. Transportation was provided by the Department of Landscape, Environment and Planning, University of Évora (we especially thank Maria Rita Menezes, Maria Ilhéu, Vanda Prazeres, and Carlos Pinto Gomes). We are grateful to João Paulo Fernandes and Nuno Guiomar for help with the selection of the $\mathrm{CO}$ areas. Maria Helena Alves (Tejo River Basin District Administration), Joao Pádua, and João Ferreira (National Water Authority) helped in the acquisition of GIS data on the stream networks. We thank Daniel Sheldon for his valuable help with Matlab scripts. We also appreciate critical comments by Clifford Kraft, Arturo Elosegi, Francisco Moreira, Francisca Aguiar, 2 anonymous referees, and Associate Editor Garry Scrimgeour. Any errors and omissions are the full responsibility of the authors.

\section{Literature Cited}

Abbe, T. B., and D. R. Montgomery. 2003. Patterns and processes of wood debris accumulation in the Queets River basin, Washington. Geomorphology 51:81-107.

AcÁcio, V., M. Holmgren, P. Jansen, And O. Schrotter. 2007. Multiple recruitment limitation causes arrested succession in Mediterranean cork oak systems. Ecosystems 10: 1220-1230.

Acácio, V., M. Holmgren, F. Rego, F. Moreira, and G. M. J. MOHREN. 2009. Are drought and wildfires turning Mediterranean cork oak forests into persistent shrublands? Agroforestry Systems 76:389-400.

Arseneault, D., E. Boucher, AND E. Bouchon. 2007. Asynchronous forest-stream coupling in a fire-prone boreal landscape: insights from woody debris. Iournal of Ecologv 95:789-801.

Bates, D., M. Maechler, AND B. Bolker. 2011. lme4: linear mixed-effects models using S4 classes. R statistical package. Version 0.999375-42. R Project for Statistical Computing, Vienna, Austria.

BENDA, L. E., AND J. C. SiAs. 2003. A quantitative framework for evaluating the mass balance of in-stream organic debris. Forest Ecology and Management 172:1-16.

Benda, L., D. Miller, J. Sias, D. Martin, R. Bilby, C. Veldhuisen, And T. Dunne. 2003. Wood recruitment processes and wood budgeting. Pages $49-73$ in S. V. Gregory, K. L. Boyer, and A. M. Gurnell (editors). The ecology and management of wood in world rivers. American Fisheries Society, Bethesda, Maryland.

Bugalho, M. N., M. C. Caldeira, J. S. Pereira, J. Aronson, and J. G. PAusAs. 2011. Mediterranean cork oak savannas require human use to sustain biodiversity and ecosystem services. Frontiers in Ecology and the Environment 9:278-286.

CAdOL, D., AND E. WoHL. 2010. Wood retention and transport in tropical, headwater streams, La Selva Biological Station, Costa Rica. Geomorphology 123:61-73.

Camia, A., J. San-Miguel-Ayanz, J. Kucera, G. Amatulli, R. Boca, G. Libertà, T. Durrant, G. Schmuck, E. Schulte, AND M. BuCKI. 2008. Forest fires in Europe 2007. Joint Research Centre and Institute for Environment and 
Sustainability, Office for Official Publications of the European Communities, Luxembourg.

Diaz-Delgado, R., F. Lloret, X. Pons, and J. Terradas. 2002. Satellite evidence of decreasing resilience in Mediterranean plant communities after recurrent wildfires. Ecology 83:2293-2303.

Diez, J. R., A. Elosegi, And J. Pozo. 2001. Woody debris in north Iberian streams: influence of geomorphology, vegetation, and management. Environmental Management 28:687-698.

Dolloff, C. A., AND M. L. WarRen. 2003. Fish relationships with large wood in small streams. Pages 179-193 in S. V. Gregory, K. L. Boyer, and A. M. Gurnell (editors). The ecology and management of wood in world rivers. American Fisheries Society, Bethesda, Maryland.

Elosegi, A., And L. B. Johnson. 2003. Wood in streams and rivers in developed landscapes. Pages 337-349 in S. V. Gregory, K. L. Boyer, and A. M. Gurnell (editors). The ecology and management of wood in world rivers. American Fisheries Society, Bethesda, Maryland.

Flannigan, M. D., M. A. KrawchuK, W. J. De Groot, B. M. WotTON, AND L. M. GOWMAN. 2009. Implications of changing climate for global wildland fire. International Iournal of Wildland Fire 18:483-507.

Gregory, K. J., R. J. DAvis, AND S. TоOтH. 1993. Spatial distribution of coarse woody debris dams in the Lymington Basin, Hampshire, UK. Geomorphology 6: 207-224.

Gurnell, A. M. 2003. Wood storage and mobility. Pages 75-91 in S. V. Gregory, K. L. Boyer, and A. M. Gurnell (editors). The ecology and management of wood in world rivers. American Fisheries Society, Bethesda, Maryland.

Gurnell, A. M., H. Piégay, F. J. Swanson, and S. V. Gregory. 2002. Large wood and fluvial processes. Freshwater Biology 47:601-619.

Haga, H., T. Kumagai, K. Otsuki, and S. Ogawa. 2002. Transport and retention of coarse woody debris in mountain streams: an in situ field experiment of log transport and a field survey of coarse woody debris distribution. Water Resources Research 38:1.1-1.16.

Harmon, M. E., J. F. Franklin, F. J. Swanson, P. Sollins, S. V. Gregory, J. D. Lattin, N. H. Anderson, S. P. Cline, N. G. Aumen, J. R. Sedell, G. W. LienKaemper, K. Cromack, and K. W. Cummins. 1986. Ecology of coarse woody debris in temperate ecosystems. Advances in Ecological Research 15:133-302.

Hassan, M. A., D. L. Hogan, S. A. Bird, C. L. May, T. Gomi, AND D. CAMpBell. 2005. Spatial and temporal dynamics of wood in headwater streams of the Pacific northwest. Iournal of the American Water Resources Association 41:899-919.

HAUER, F. R. 1989. Organic matter transport and retention in a blackwater stream recovering from flow augmentation and thermal discharge. Regulated Rivers: Research and Management 4:371-380.

Hothorn, T., F. Bretz, AND P. Westfall. 2008. Simultaneous inference in general parametric models. Biometrical Iournal 50:346-363.
Huxman, T. E., B. P. Wilcox, D. D. Breshears, R. L. Scott, K. A. Snyder, E. E. Small, K. Hultine, W. T. Pockman, AND R. B. JACKSON. 2005. Ecohydrological implications of woody plant encroachment. Ecologv 86:308319.

IPCC (Intergovernmental Panel on Climate Change). 2007. Climate change 2007: the physical science basis. Intergovernmental Panel on Climate Change Secretariat, Geneva, Switzerland. (Available from: Intergovernmental Panel on Climate Change c/o WMO, 7bis, Ave. de la Paix, 1211 Geneva 2, Switzerland.)

Jones, T. A., And L. D. DAniels. 2008. Dynamics of large woody debris in small streams disturbed by the 2001 Dogrib fire in the Alberta foothills. Forest Ecology and Management 256:1751-1759.

KRAFT, C. E., AND D. R. WARREN. 2003. Development of spatial pattern in large woody debris and debris dams in streams. Geomorphologv 51:127-139.

Kraft, C. E., D. R. Warren, And W. S. Keeton. 2011. Identifying the spatial pattern of wood distribution in northeastern North American streams. Geomorphology 135:1-7.

LienKAEMPER, G. W., AND F. J. SwANSON. 1987. Dynamics of large woody debris in streams in old-growth Douglasfir forests. Canadian Journal of Forest Research 17: 150-156.

Lorenzo-Lacruz, J., S. M. Vicente-Serrano, J. I. LÓpezMoreno, E. Morán-Tejeda, and J. Zabalza. 2012. Recent trends in Iberian streamflows (1945-2005). Iournal of Hvdrology 414/415:463-475.

Marcus, W. A., J. Rasmussen, And M. A. Fonstad. 2011. Response of the fluvial wood system to fire and floods in northern Yellowstone. Annals of the Association of American Geographers 101:21-44.

MellinA, E., AND S. G. HiNCH. 2009. Influences of riparian logging and in-stream large wood removal on pool habitat and salmonid density and biomass: a metaanalysis. Canadian Journal of Forest Research 39: 1280-1301.

Merten, E. C., J. Finlay, L. Johnson, R. Newman, H. Stefan, AND B. VONDRACEK. 2010. Factors influencing wood mobilization in streams. Water Resources Research 46: W10514.

Merten, E. C., J. Finlay, L. Johnson, R. Newman, H. Stefan, AND B. VONDRACEK. 2011. Environmental controls of wood entrapment in upper Midwestern streams. Iournal of Hvdrologic Processes 25:593-602.

Minshall, G. W., J. T. BROCK, AND J. D. VARley. 1989. Wildfires and Yellowstone's stream ecosystems. BioScience 39:707-715.

Minshall, G. W., C. T. Robinson, and D. E. Lawrence. 1997. Postfire responses of lotic ecosystems in Yellowstone National Park, USA. Canadian Iournal Fisheries and Aquatic Sciences 54:2509-2525.

Moreira, F., O. Viedma, M. Arianoutsou, T. Curt, N. Koutsias, E. Rigolot, A. Barbati, P. Corona, P. Vaz, G. Xanthopoulos, F. Mouillot, and E. Bilgili. 2011. Landscape-wildfire interactions in southern Europe: implications for landscape management. Iournal of Environmental Management 92:2389-2402. 
Moriondo, M., P. Good, R. Durao, M. Bindi, C. Giannakopoulos, And J. Corte-Real. 2006. Potential impact of climate change on fire risk in the Mediterranean area. Climate Research 31:85-95.

Naiman, R. J., E. V. Balian, K. K. Bartz, R. E. Bilby, And J. J. LATTEREll. 2002. Dead wood dynamics in stream ecosystems. Pages 23-48 in W. F. Laudenslayer, P. J. Shea, B. E. Valentine, C. P. Weatherspoon, and T. E. Lisle (editors). Proceedings of the symposium on the ecology and management of dead wood in western forests. General Technical Report. PSW-GTR-181. US Department of Agriculture Forest Service, Washington, DC.

Nakamura, F., and F. J. Swanson. 1993. Effects of coarse woody debris on morphology and sediment storage of a mountain stream system in western Oregon. Earth Surface Processes and Landforms 18:43-61.

NAKAMURA, F., AND F. J. SwANSON. 2003. Dynamics of wood in rivers in the context of ecological disturbance. Pages 279-297 in S. V. Gregory, K. L. Boyer, and A. M. Gurnell (editors). The ecology and management of wood in world rivers. American Fisheries Society, Bethesda, Maryland.

NAveH, Z., AND S. Lieberman. 1984. Landscape ecology. Springer-Verlag, New York.

NFA (Portuguese National Forest Authority). 2010. $5^{\text {th }}$ National Forest Inventory 2005. National Forest Authority, Lisbon, Portugal. (Available from: http:/ /www.icnf. pt/florestas/ifn/ifn5/relatorio-final-ifn5-florestat-1)

PAusAS, J. G. 1999. Mediterranean vegetation dynamics: modelling problems and functional types. Plant Ecology 140:27-39.

Pinheiro, J., D. Bates, S. DebRoy, D. Sarkar, R. Development Core TeAm. 2011. nlme: linear and nonlinear mixed effects models. R statistical package. Version 3.1-102. R Project for Scientific Computing, Vienna, Austria.

Resh, V. H., A. V. Brown, A. P. Covich, M. E. Gurtz, H. W. Li, G. W. Minshall, S. R. Reice, A. L. Sheldon, J. B. Wallace, AND R. C. Wissmar. 1988. The role of disturbance in stream ecology. Iournal of the North American Benthological Society 7:433-455.

RichmOND, A. D., AND K. D. FAusch. 1995. Characteristics and function of large woody debris in subalpine Rocky Mountain streams in northern Colorado. Canadian Journal of Fisheries and Aquatic Sciences 52:1789-1802.

Romme, W., M. Boyce, R. Gresswell, E. Merrill, G. Minshall, C. WhitLOCK, AND M. TuRnER. 2011. Twenty years after the 1988 Yellowstone fires: lessons about disturbance and ecosystems. Ecosvstems 14:1196-1215.

SANTOS, M. 2010. Encroachment of upland Mediterranean plant species in riparian ecosystems of southern Portugal. Biodiversitv and Conservation 19:2667-2684.
Silva, J. S., P. Vaz, F. Moreira, F. Catry, and F. C. Rego. 2011. Wildfires as a major driver of landscape dynamics in three fire-prone areas of Portugal. Landscape and Urban Planning 101:349-358.

Sluiter, R., AND S. Jong. 2007. Spatial patterns of Mediterranean land abandonment and related land cover transitions. Landscape Ecologv 22:559-576.

Spies, T. A., J. F. Franklin, And T. B. Thomas. 1988. Coarse woody debris in Douglas-fir forests of western Oregon and Washington. Ecology 69:1689-1702.

Stahl, K., H. Hisdal, J. Hannaford, L. M. Tallaksen, H. A. J. van Lanen, E. Sauquet, S. Demuth, M. Fendekova, and J. JóDAR. 2010. Streamflow trends in Europe: evidence from a dataset of near-natural catchments. Hydrology and Earth System Sciences 7:5769-5804.

StrAHLER, A. 1957. Quantitative analysis of watershed geomorphology. Transactions of the American Geophvsical Union 38:913-920.

SuberKRopP, K. F. 1998. Microorganisms and organic matter decomposition. Pages 120-143 in R. J. Naiman and R. E. Bilby (editors). River ecology and management. SpringerVerlag, New York.

SWANSON, F. J. 2003. Wood in rivers: a landscape perspective. Pages 299-313 in S. V. Gregory, K. L. Boyer, and A. M. Gurnell (editors). The ecology and management of wood in world rivers. American Fisheries Society, Bethesda, Maryland.

Thomas, A. D., R. P. D. Walsh, and R. Shakesby. 2000. Postfire forestry management and nutrient losses in eucalyptus and pine plantations, northern Portugal. Land Degradation \& Development 11:257-271.

Vaz, P. G., D. R. Warren, P. Pinto, E. C. Merten, C. T. Robinson, AND F. C. REGO. 2011. Tree type and forest management effects on the structure of stream wood following wildfires. Forest Ecology and Management 262:561-570.

YounG, M. K. 1994. Movement and characteristics of streamborne coarse woody debris in adjacent burned and undisturbed watersheds in Wyoming. Canadian Journal of Forest Research 24:1933-1938.

Young, M. K., E. A. Mace, E. T. Ziegler, And E. K. SutHerlAND. 2006. Characterizing and contrasting instream and riparian coarse wood in western Montana basins. Forest Ecology and Management 226:26-40.

ZeLt, R. B., AND E. E. WoHL. 2004. Channel and woody debris characteristics in adjacent burned and unburned watersheds a decade after wildfire, Park County, Wvoming. Geomorphology 57:217-233.

Zuur, A. F., E. N. Ieno, N. Walker, A. A. Saveliev, and G. M. SMith. 2009. Mixed effects models and extensions in ecology with R. Springer, New York.

Received: 7 June 2012

Accepted: 5 November 2012 